Relocating kampung, Rethinking Community: Salatiga’s Festival Mata Air

\author{
Alexandra Crosby
}

As part of the collective effort of this volume to understand the cultural spaces in Indonesia after the end of the New Order, this paper argues that small-scale arts festivals are key sites generating changing notions of place and community in contemporary Java. I take as my subject an annual activist festival that began in 2007, Festival Mata Air (FMA) and its interactions with three Salatiga kampung neighbourhoods. Along with other festivals that emerged around the same time, such as the Forest Art Festival in Randublatung, FMA generates a fresh culture of protest, opens up the kampung as a space of public engagement and provides artists and performers with a viable alternative to curator-driven exhibitions and events.

This paper shows the potential that exists for dynamic local identities to interact meaningfully with the global, expanding the social imaginary of the kampung. During a festival, activists deconstruct the very idea of the kampung, by working with the community within the kampung rather than the kampung as an official entity, and by creating an affinity space, which can also be thought of as an activist kampung.

Tapping the springs of Salatiga If a city can be said to have an identity, Salatiga's is undeniably linked to water. It is dotted with hundreds of fresh water springs connected by canals, rivers and creeks that provide water for much of the lower altitude regions of Central Java. The Dutchbuilt Jelok power station has long been the main provider of electrical power for Salatiga. Jelok gets its water from Tuntang river, which flows out of Rawa Pening lake, which in turn receives its water from Telemoyo Mountain. Salatiga residents, until recently, have prided themselves on excellent tap water that runs down from the mountains behind it throughout the year. ${ }^{1}$ But battles to exploit or protect water sources have also become part of the shifting identities of many Salatiga communities. The most recent of these communities, and the one examined in this paper, is Tanam Untuk Kehidupan (TUK). TUK formed in 2005 when the artist Rudy Ardianto and his family returned to Salatiga after living in Australia for ten years. The word tuk means 'water source' in Javanese, and the phrase Tanam Untuk Kehidupan in Indonesian translates as 'planting for life'. By early 2007, when Festival Mata Air began, there were about twenty artists, activists and scientists from all over Salatiga that were active in TUK.

Festival Mata Air began in July 2006 when TUK negotiated to borrow a disused council building in the centre of Salatiga to use as their headquarters for an

1 Tap water in cities in Indonesia is rarely potable. See Kurniasih (2008) 
ambitious program of events over the next few months, culminating in a three-day art, music and education event themed around water. TUK secured sponsorship from the cigarette company Djarum and funding from local government. The festival has since become an annual event in Salatiga, growing steadily in size and adapting in form.

Senjoyo was the site of the first (2006) and fourth (2009) festivals. The spring at Senjoyo is the main source for the municipal water supply and the two textile factories in the city. It is also used for irrigation downstream of Senjoyo river. There is a public pool at the spring, which is crowded every day, both_with locals, who use it for bathing, laundry and washing dishes-, as well as_tourists, who enjoy its_beautiful forest setting, spiritual significance and lack of admission fee. ${ }^{2}$ Although largely regulars, the people that use Senjoyo do not for the most part reside there. Like the activists, they are transient, guests who share and activate a common locality. During the first festival, the spring played an important role, as a gathering point and performance site. It was repeatedly referenced in artworks and performances (for example Indra Yanti’s Menjahit Sampah, 'Sewing Rubbish’, Senjoyo, 2006).

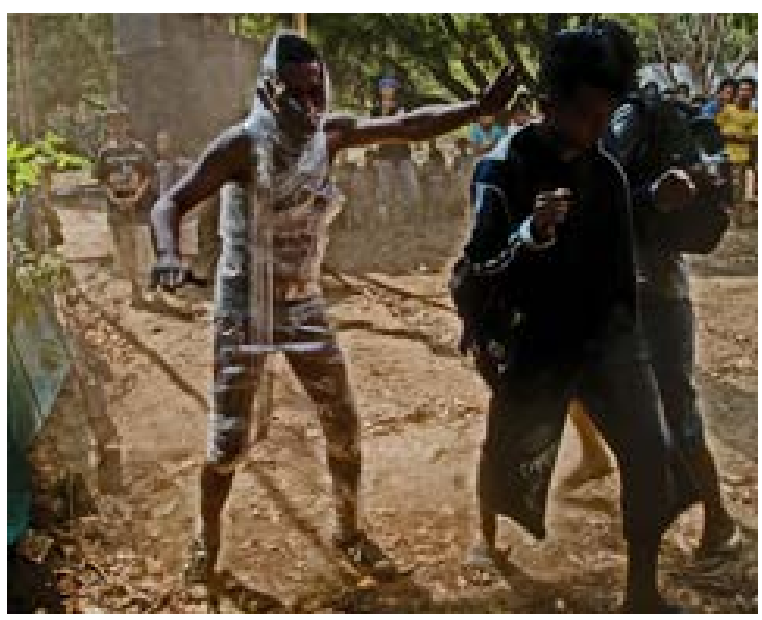

Figure 3.1 Performance 'Plastic Man', Festival Mata Air, kampung Senjoyo, Salatiga, 2006. Photo: Alexandra Crosby

The second Festival Mata Air was staged at a kampung in Salatiga's CBD called Kalitaman ('river park' in Javanese). Kalitaman is located below both a large shopping centre and the 'main drag' of Salatiga, where many residents work, and from which a large quantity of waste makes its way through the kampung waterways. One of Kalitaman's springs, traditionally used as a public bath for men only, has dried up completely. Two springs remain, one of which has been converted to a public swimming pool with an entrance fee, owned and run by the city council. As_at Senjoyo, the other spring is used for bathing, laundry, washing dishes, and relaxation. Kalitaman was chosen by TUK not only because of the environmental problems it faces, but also because the kampung had already fought for its water rights in the 1990s, when an outside company had tried to take over all three springs (Crosby 2007).

$2 \quad$ Although the pool was built in colonial times, the spring itself is ancient, and bathing in it was believed to secure long life. 


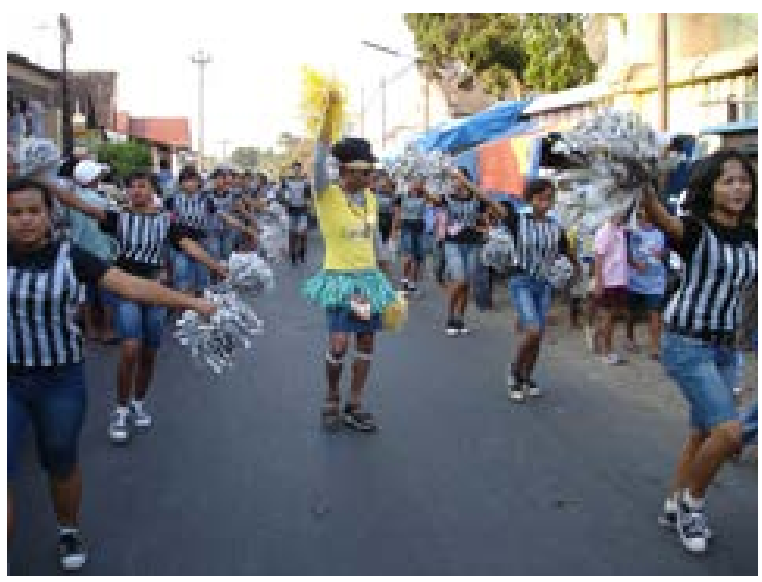

Figure 3.2 Group performance 'Rubbish Cheerleader', Festival Mata Air, kampung Kalitaman, Salatiga. 2007. Photo: Alexandra Crosby

The 2008 festival was held at Kalimangkak, (which ironically translates as 'dirty creek'). The waterway is managed (or mismanaged) by a co-operation between no less than four separate RT. ${ }^{3}$ On one side of the creek are privately-owned rice fields, irrigated by the creek itself, and a TPSS (Tempat Pembuangan Sampah Sementara), council-run temporary rubbish tip that is used to sort and store rubbish that is then be transported to the main city tip. There is also a hotel \& café (Hotel Kalimang \& Café Kelinci) as well as many homes. Three springs are connected to the creek and used by kampung residents for bathing and washing.

Typically, the festival programs include a range of music on a number of stages, from the local high school choir to nationally famous punk bands, outdoor sculptures, games, traditional performance, a market place for independent producers, workshops, and children's activities. In creating Festival Mata Air, TUK formed an identity in response to the physical geography of Salatiga. They then performed that identity by activating existing kampung in the city. In doing so, the collective also engaged with globally circulating ideas of community, art and environmentalism that influenced their own definitions of 'local'.

The kampung quandary

How do we define or translate kampung, a word reflecting on the ways people relate to each other and their localities, a term of long-standing fluidity now being explicitly reinterpreted and reclaimed ? The following translations of 'kampung' and its derivatives are from Kamus Indonesia-Inggris (Indonesian-English Dictionary ) (Echols, Shadily, Wolff and Collins 1997, 258.)

kampung: 1 village. 2 quarter. 3 residential area for lower classes in town or city

perkampungan: 1 settlement. 2 gathering place

kampungan: countrified, boorish

The idea of the kampung as both_a physical site and a community of people is an important part of TUK's practice. As Yoshi Fajar Kresno Murti points out in Chapter

3 Rukun Tetangga (RT) is the smallest administrative unit of Indonesian society and defines the official boundaries of a kampung. 
2 of this volume (Kresno Murti p 4.15) 'kampung' is a highly flexible term which can convey varying perspectives on the realities it describes: it may lack a direct English translation in part because it has always been conflicted, in various ways. Its slippery meanings - a village, a neighbourhood, a slum, a home - are all important and evoke a number of questions: Can kampung function as the conceptual equivalence to the English 'community', or the German 'Gemeinschaft'? Is it possible to speak of a 'virtual kampung' in the way 'virtual communities' have been coined? Can there be a 'global kampung' like a 'global village'? Can a kampung be temporary? As TUK uses kampung as the site of their_cultural activism, these questions become inherently_part of their practice.

In Indonesia, kampung has many associations, one of which is the ongoing dialogue between community and nation. In a similar way to the interplay_between national and regional languages, the space of the kampung, how it is created and how it creates itself, defines what is local in a national context. While the role of a kampung can be devised and imposed at a national level, the kampung can also become a unit for organising dissent.

In her thesis on the development of Internet practices in Indonesia (Lim, 2005), Merlyna Lim draws on Foucault's term the 'Panopticon of surveillance' to describe how the kampung system operated during the New Order. Lim points out that security measures including the culture of reporting guests (outsiders) to kampung authorities were imposed by the state after the anti-communist sweepings of 1965. During that time, Lim argues, the kampung system performed much the same role as the high-tech surveillance systems of major world cities today, albeit much more simply and cheaply. People generally accepted unquestioningly that the state had the right to monitor the comings and goings within their kampung, thus relinquishing any notion of civic space, and they were also encouraged to be suspicious of strangers. The RT system along with the Siskamling-Sistem Keamanan Lingkungan (neighbourhood community watch) were part of the territorializing project of the New Order regime which sought to bring existing social divisions into the service of the state as well as developing new mechanisms for control (Barker 1999). Besides as a system of surveillance, the kampung also provided a way to quantify groups of people, to conduct census, keep track of dissidents, in short, control the population. ${ }^{4}$

However, the kampung was not simply an imposition by the State on the population. Laine Berman describes the paradox that emerged in the visual language at the end of the New Order when the role of the kampung as a building block of the nation was challenged by the rising dissent. Under Suharto, the gapura (entrance way) to the kampung was usually decorated to reflect the ideology of the regime: cast or sculpted statues of revolutionary heroes, images of ethnic unity, maps of Indonesia, the two-finger symbol of the national family planning campaign dua anak cukup'(two children are enough). ${ }^{5}$ Meanwhile on the streets and alleyways of the kampung, very

$4 \quad$ Rachmah Ida also makes reference to the use of kampung structures by the New Order state for population control and surveillance, in her discussion of the gardu community guard house in chapter 4 of this volume.

5 The motto 'Dua Anak Cukup' was part of Suharto's population control program that was launched in 1974. The campaign included billboards, songs, and subsidised family planning programs. 
different sentiments about the regime were reflected in posters, banners, T-shirts and graffiti (Berman 1999). These expressions of kampung operated in two directions, from the state about citizens and from citizens about the state.

Thus the term 'kampung' has come to have important connotations of resistance for activists. They often identify themselves_as kampung and kampungan (uncultivated, low class), drawing on a positive image of the kampung as a site of egalitarian collective identity. This image is grounded in a genealogy of activism that precedes the controlling mechanisms of the New Order and needs to be considered along with the negative pictures of the kampung as a tool of surveillance presented above. In some cases dating back to collective opposition to colonialism, this heritage is celebrated today in the names and practices of music and theatre groups. ${ }^{6}$

Take, for example, the Yogyakarta protest band Dendang Kampungan and the Solo performance troupe Wayang Kampung Sebelah, both of whom performed at Festival Mata Air on multiple occasions. Dendang Kampungan- DK (dendang means 'happy chants or songs') prides itself on being able to perform protest songs in any situation with any number of members, with or without rehearsals. The band uses the term 'kampungan' defiantly to express their inclusiveness and lack of concern with professionalism. During Dendang Kampungan performances, the number of participants is not fixed. Everyone has the right to have a creative role in the process of making the songs, including the lyrics, the rhythm, or the instruments used. Individual authorship of songs is not acknowledged. The term 'kampungan', generally understood to imply lower class vulgarity and lack of style, is here celebrated as an indicator of egalitarian participation and inclusiveness.

Wayang Kampung Sebelah (Wayang from the next-door neighbourhood) also employs the idea of a kampung as a point of resistance. This contemporary version of Javanese puppet theatre uses Indonesian language, rather than Javanese, so as not to be exclusive. Unlike 'traditional' wayang, the performance uses modern musical instruments and puppets made from cardboard which appropriate traditional wayang characters and also represent figures from contemporary popular culture such as the infamous Inul. The shows tackle issues of prostitution, government corruption, environmental destruction, and globalisation played out and discussed in kampung communities full of gossiping residents. The performance developed for FMA in 2008 told the story of a natural water source exploited by corporate interests and a corrupt local council. ${ }^{7}$

These examples illustrate the varied, contested, shifting nature of contemporary understandings of the terms 'kampung and 'kampungan'. Long used in dominant discourse with connotations of uneducated rural simplicity and vulgarity, mobilised during the New Order within a vocabulary of objectification and depoliticisation of the masses, today these terms are being reclaimed and worn with pride. Such processes are evident not only in small-scale arts groups, but also in mainstream popular culture. The famous rock band Slank titled their 1992 album Kampungan. Another example is the television show Empat Mata ( literally 'Four

\footnotetext{
${ }^{6}$ For an in depth discussion of the 'remixing' of anti-colonial and post New Order activism, see Crosby 2013.

$7 \quad$ Anotherexample is the participatory media group Kampung Halaman , which also refers to the concept of the kampung to mean 'grassroots'
} 
Eyes), hosted by Tukul Arwana, represented as wholly 'kampungan' in his language and humour. The huge popularity of this program suggests a degree of identification by viewers with Tukul's struggles with the increasingly globalised experiences of everyday life. The term kampungan, it would seem, is closely connected to the way many Indonesians think of themselves, and the shifts in its meanings reflect changes in and re-evaluations of their sense of self.

In the arts generally, kampung is often interchanged with 'community' in discussions focusing on cultural participation. The idea of seni kerakyatan (People's Art) from the Sukarno era has seemingly coalesced with global trends in visual arts that prioritise participation. These trends involve social contexts and relations, what French critic Nicolas Bourriaud calls 'relational aesthetics' (Bourriaud 2002). In many arts projects in Java, well before Festival Mata Air, seni kampung was used by artists and arts writers to refer to participatory art that either engaged a community or was produced directly by a community. Today the term community or komunitas is widely employed and celebrated in Indonesia. Yet the concept of community brings its own set of ambiguities. Some of these ambiguities are part of the appeal of community as a tool for analysis of kampung.

\section{The community quandary}

In her study of site-specific art, One Place After Another, Miwon Kwon points to the way community can describe very different groups. "On the one hand, the term 'community' is associated with disenfranchised social groups that have been systematically excluded from the political and cultural processes that affect, if not determine, their lives" (Kwon 2002, 112). When we speak of 'the gay and lesbian community', for example, or 'refugee communities', we are referring to groups that are bound together by their common experiences of oppression. On the other hand, community is used to refer to the groups that carry out this oppression, for example 'the business community'.

In the West as in Indonesia, 'community' connotes belonging and inclusiveness. But conservative, romanticized notions of community can also exclude people. Gillian Rose (1997) argues that there must be a move away from the search for some pure concept of community based on 'territorialized and territorializing boundaries' because of the exclusion those boundaries create. Community is now applied to a wide array of social forms for which connotations of place are not relevant. Since we now talk of 'online communities', where people gather virtually, the concept of community no longer always has associations of a physical site. Like 'kampung', 'community' is changing and through events like Festival Mata Air, activists participate in the process of redefinition.

So, what kind of community is Festival Mata Air? Is 'community' the best way to describe the practices that make up Festival Mata Air, or are there other ways that can reconsider the kampung as a site and a practice? For FMA, the geographical site is important, even defining, but it is not the entirety of the event.

One alternative way the to describe the social relations that activists draw out of 'kampung' and 'community' comes from American theorist James Gee who speaks of 'affinity spaces' (Gee 2005). Gee analyses some of the social forms commonly thought of as communities, for which the term may not be the best fit. He focuses particularly on networked learning environments to show that what happens within them is more than what we generally define as community activity Gee suggests that 'community' is the wrong way to think about these groups, who work in the same space, but move in and out of it, arguing that an 'affinity space' better describes the 
way members share knowledge and experience around a particular idea or set of ideas, particularly online. Affinity spaces are characterized by voluntary affiliations rather than a shared physical space.

Gee's examples are affinity spaces created around 'real-time strategy' computer games, but the definition also fits for a festival like FMA, where the grouping is voluntary, temporary and mobile. When a festival like FMA occurs in a kampung like Kalitaman, the kampung may be the site of performance, but it also becomes much more than that. As well as a physical space, it is also a space of interaction. It becomes a space where multiple communities interact, renew previous affinities, form new affinities, imagine the potential of future affinities, and perhaps most importantly, learn together. As they make a festival, activists and residents do form a community within a kampung, but they also move in and out of affinity spaces, all the time generating new senses of place.

To think of a kampung as an affinity space begins to challenge the idea that places have single, essentialist identities. This is also the challenge made by geographer Doreen Massey when she argues for a progressive sense of place (Massey 1994). It is from that perspective that it is possible to envisage kampung not only as the site of transformative social projects but as active agents of change. An activist kampung is actually generated from FMA. This kind of kampung is an affinity space, but it is also strongly linked to a real geography. In this case, it is inseparable from the springs and waterways of Salatiga. It must be thought of as a place. However, in this newly imagined kampung, it is the activity that occurs within the affinity space of the festival that produces this sense of place.

Massey argues for an alternative interpretation of place based on particular constellations of social relations. A place, she says, is better thought of as the point of intersection of multiple networks. This works well for imagining the festival as a place. And then, for imagining how this place is connected to global flows, to other places, not just during the moment that the festival occurs, but over multiple moments at multiple scales. Massey argues that such a definition of place "allows a sense of place which is extroverted, which includes a consciousness of its links with the wider world, which integrates in a positive way the global and the local” $(1994,155)$. To examine these links, let us begin by looking at how TUK has moved through physical places, working with existing kampung by forming relationships to people and environments.

Festival Mata Air: a mobile sense of place

Retrospectively, FMA can be viewed as a series of events that map the water sources and streams in Salatiga. Each incarnation of the festival has focused_-not only on a kampung, but on a particular spring. The map is multi-dimensional, showing how the friction generated within festival spaces is a form of social change. In one sense, the collective has been driven from one point to another by the various administrative boundaries of the kampungs of Salatiga. In another sense, they have followed the natural paths of the water sources and passageways throughout the city and it is these paths that have coincided with the organic networks of artistic collaboration.

The journey of Festival Mata Air to three neighbourhoods, Senjoyo, Kalitaman and Kalimangkak, is a story of multiple tensions between activists and kampungs but also of tensions within kampungs. It shows what can happen when an affinity space is created_around a local environmental issue. This space can challenge the imagined community of the kampung, generating another sense of place, a counter imaginary, within that kampung. 
TUK's strategy during each festival has been to draw kampung residents together around their common water source. But the relationship between a kampung and its water is not necessarily simple. There are those who use the springs every day, for washing, swimming, bathing, and there are those with the power to make decisions about the springs as resources. The most revealing of these relationships is between TUK and the kampung of Kalitaman. The internal politics of the kampung that hosted Festival Mata Air 2007 forced a redefinition of TUK's collective identity, challenging the way they imagined themselves as a 'local' organisation.

Festival Mata Air 2007 was generally felt within TUK to have been a success. Grievances from residents were limited, media reports (newspaper and radio) had been all positive, and several of Kalitaman's youth had subsequently joined TUK, attending and_organising meetings, and signing up for workshops, exhibitions and other events outside Kalitaman. There was excitement and enthusiasm about working at Kalitaman again on the 2008 festival. There was also continuing discussions around an idea raised during workshops of Festival Mata Air 2007, that Kalitaman become as an 'eco-kampung.' As activists imagined it, the kampung would take responsibility for various collective practices such as water filtering, waste reuse, composting, and biodegradable packaging so their neighbourhood could serve as a model of sustainability, and in turn, attract attention, funding, and tourism.

In April 2008, TUK organised a community forum to discuss the 'ecokampung' concept and the upcoming festival in November 2008. As with other community meetings, the time, agenda, and invitations were organised through the Bapak Rukun Warga, the neighbourhood head, who also secured the Kalitaman community hall as a venue. This was the same process that had been used on many occasions leading up to Festival Mata Air 2007. But this time only a handful of people attended, and those who did raised several concerns based on gossip that was circulating in Kalitaman, namely that TUK was exploiting the kampung of Kalitaman.

The rumours were, firstly, that TUK had made huge profits from Festival Mata Air 2007 selling photographs of the kampung in Australia and, secondly, that TUK had received overseas funding, of which it had not shared with the Kalitaman community. These rumours begun with confusion around information that begun on social networking sites, announcing and documenting TUK's activities in Australia. In fact, photographs of the festival had been used to raise awareness in Australia but none of these photographs were sold, and they were exhibited only in a small councilfunded Community Arts Centre in Sydney ${ }^{8}$. Secondly, TUK, at that stage, had not received any funding from overseas sources except for personal donations from fellow activists and a meager amount from a small 'Sponsor a Tree' program it had tried to establish in Australia.

The accusations were denied, but clearly needed further discussion with a wider audience, TUK attempted to organise a second forum but was not granted permission to use the community hall. Taking a different tack, they organised a 'pemuda' (youth) meeting. The twenty or so young people who attended expressed surprise that there had been grievances raised by their elders and they expressed general enthusiasm to be involved in more TUK activities and programs. Creative brainstorming and planning began for future campaigns.

Shortly after this meeting, TUK received four formal letters, from each of the

8 An exhibition titled 'Art for Earth's Sake' was held at Pine Street Community Arts Centre as part of the Gang Festival, 2007. 
four neighbourhoods, (rukun warga, $R W$ ), that form Kalitaman, stating that Kalitaman would not host another festival. The letters raised several complaints; that children's learning had been disrupted during the week-long activities; that there was not enough security on site; that there was drunkenness; and that there was a general disturbance of the peace. Secondly, they accused TUK organisers of going 'behind their backs' by organising the youth meeting, and not respecting the kampung's established code of conduct. The letters bore the official signatures, letterheads and stamps typical of New Order bureaucratic style, and were expressed in the formally correct language of Suharto's presidential speeches, which provided a general model for government discourse, as described by Virginia Hooker (1993, 282). While TUK had relied on informal mutuality, the neighbourhood officials had seemingly reverted to a statist sense of locality, where kampung were defined in opposition to each other and kampung affairs were determined by the hierarchal structures within them.

The real reasons for the degraded relationship between the kampung authorities and TUK are a matter of conjecture. Around the time of Festival Mata Air 2007, plans were made to convert the large spring at Kalitaman (Pemandian Kalitaman), to a bottling source for the Salatiga branch of the national government water company, PDAM (Perusahan Daerah Air Minum). While there has been some media coverage of the deal (Suara Merdeka, 2007), there has been very little actual community consultation regarding the change of use or its impact on residents. TUK considers it unlikely that the sale of the spring and the refusal of the kampung authorities to host Festival Mata Air 2008 are coincidental.

Other reasons are more publicly identifiable. TUK did not offer money to the kampung council to continue their activities. From the beginning of the process, this had been a point of contention. It had been hinted on several occasions, by members of the council, that money was expected, that this was the budaya 'local custom' for staging such events ${ }^{9}$. TUK, as a young, small non-profit organization was both unable and unwilling to offer. They preferred a model based on mutual (non-monetary) reciprocation, and argued that this was budaya for community events elsewhere, pointing out that the kampung benefited from the profits of paid parking during the event and an increase in local business revenue.

TUK's mistake at Kalitaman was to assume a common imaginary with kampung authorities. For TUK this imaginary was based partly on the activist history of the kampung, particularly the resistance to the sale of the spring in 1994. This history is certainly important to the identity of many Kalitaman residents, but the idea that it defines the 'sense of place' of the entire kampung is certainly a misconception. To take a more famous example, Uluru may be a site of struggle to many people, a site that represents the long ongoing battle by Indigenous people in Australia to reclaim their land. But to others, even those who know its history, the place may be thought of as Ayers Rock, may be remembered as the site of a romantic holiday, or may only be recognised as the image of a natural wonder seen on a calendar at the dentist's surgery.

While the story of the protest to protect the spring at Kalitaman is publicly known, it does not mean the springs are forever safe from privatisation. The

$9 \quad$ It is in fact 'customary' for neighbourhoods to be compensated for any use of the 'public space' in their jurisdiction, i.e. closing the street down for a wedding or religious ceremony. 
neigbourhood heads had clearly changed since 1994, as had the nature of their relationship with their constituents. Those in power now imagined the festival as they did the springs, as a source of potential profit. They clearly felt that that they had legitimate ownership over the identity of their kampung. They may have even been convinced that they had the community's best interests at heart. But all the local participants of the festival, who had sung, danced, joined workshops, celebrated, and planted gardens at FMA had also embodied a sense of place. These differences problemitize the notion of place as a single, coherent identity.

So what does TUK - a young, creative activist collective - do in such a situation, with a conflict over the sense of place of their festival site? After two great festivals, TUK's sense of purpose was strong, its identity robust, and its energy building. TUK packed up its festival and moved on to another kampung. The third festival, held at Kalimangkak,in 2008, was even bigger and better.

Interestingly, a number of young residents of Kalitaman, the very same people who had facilitated the youth meeting, joined the collective and kept working on the project. They still lived at Kalitaman, where they always had, but they worked now in a greater sphere, they bagan to define their own territories, expanding their kampung. For them, the community of TUK had drawn them out of Kalitaman, at the same time drawing them more deeply into its conflicted sense of place. It had shown their kampung for what it was, a group of people living in close proximity, who nevertheless had different interests and attitudes in regards to particular issues. In Kalitaman, people's shared identities are embodied through the neighbourly relations of the kampung. These relations, because they share a physical site, may seem solidly 'real'. But the kampung is also fragile. Through Festival Mata Air, the young people realized they are bound by neither the physical nor imaginary borders of Kalitaman. They could, in fact, participate in multiple communities, move in and out of affinity spaces, and invent their own notions of kampung.

What the experience of Kalitaman did for TUK, by forcing the collective to relocate, was to challenge the idea of the kampung as a static, rooted community. The way FMA occurs at multiple sites shows that part of the work done in creating a festival is to develop representations of place that can be transported, reformed and re-imagined.

A global kampung

When FMA's kampung dislocates, moving from Kalitaman to Kalimangkak on the other side of the city, it begins a momentum which allows it to move even further. It is now that we can start to talk about the global interaction of this small local event. How this movement produces a global sense of place is a messy and sticky process. When FMA moves from one kampung to another, what is it that actually moves?

Firstly, it is representations that are circulated. These representations come in many forms, but most prolific is photographic documentation of the festival. Thousands of digital photographs circulate the internet after each festival, catalysed by social networking sites such as Flickr and Facebook. Tagged with 'Festival Mata Air' or the acronym 'FMA', these images build up a visual sense of place that is constantly referred to by activists and artists, both those who were present and those who were not. Also, the brand of the festival moves with the activists that produce it. This includes the mottos, logos, and websites created to publicise the festival, which also document, represent and reproduce it.

These representations must also be understood as a set of ongoing practices that continue to generate place. For example, the images on Flickr and Facebook 
spark discussions that evaluate the festival's success and begin plans for its future. These discussions are held in multiple languages, and, because information about the festival is rapidly circulated on a global scale, include communication between local residents, international journalists, researchers, and potential funders. These communications all feed back into a sense of place that is connected to the global as much as it is to the Kalitaman. It is through these processes, that TUK engages with global discourses on environmentalism and raises awareness of local issues on a global scale. The kampung administrators are left in the dust of these processes, still stamping their official letters that complain about the noise disruption during Festival Mata Air.

Clearly, this trajectory of place, expanding outwards from the physical space of the festival sites to the virtual spaces the festival generates is important for a kind of activism that is tactical and effective. To be able to carry on with its work, FMA must be able to move and change, remaining an affinity space and constantly building a more progressive sense of place for the kampung with which it works.

\section{Conclusion}

The end of the New Order in Indonesia gave rise to a diversity of cultural spaces in which 'new' forms of activism took place. Many of these forms, such as the festivals discussed in this paper, have emerged as people have redefined the notion of kampung and their own connections to their neighbourhoods and their natural environment. This cultural activism has made it increasingly difficult to continue thinking of the association of particular places, with what was previously defined as 'traditional culture' OR with particular forms of cultural activity, as something static. ${ }^{10}$

FMA demonstrates that within new cultural spaces,_place is constantly generated. The process of challenging those who consider themselves authorities_over a place or guardians of a community interrogates the assumption that local is something fixed and closed. TUK's practices continue to generate a sense of place in virtual spaces, which can also challenge the idea that the identity of a place is bound to its physical site.

In terms of global significance, festivals like FMA are important in showing that global interaction happens where people make it happen. While very focused in their subject matter, the exchanges that occur before, during and after Festival Mata Air are local, national and global in scale. -In this way, a_small kampung in Salatiga can be thought of as just as global as a Jakarta-based transnational business.

Delving into the complexities of what is meant by 'local' in a place like Kalitaman reveals that it is relationships between people that produce place. This production is impossible to describe simply in terms of interactions between centreperiphery or artist-audience. These places are not only recreated in different physical as well as virtual spaces, but they continue to be reproduced in these spaces. This is a generative, mobile sense of place, a different kind of local, what might be thought of as a mobile kampung. This sense of place is generated by working relationships between people, by the artworks and performances they produce, not by

\footnotetext{
${ }^{10}$ Two major forces appear have influenced these developments, the political changes which occurred at the end of the New Order period, result in increased activism in diverse forms, and global technological change. The availability of relatively cheap digital video cameras combined with newly claimed political freedoms, for example, can be seen in the proliferation of video activism in Indonesia. See Crosby, Thajib et al. (2011) and Edwin Jurriens in this volume.
} 
administrative powers.

These activists are shaped by the geographical places in which they work, but their struggles also define the identities of those places in ways that go beyond traditional notions of kampung or community. _Their_festivals can be understood as more than mixes of traditional and contemporary culture, or art and activism, but as collections of cultural practices that actually do something, generating place every step of the way.

\section{References}

Barker, Joshua. 1999. "Surveillance and Territoriality in Bandung” In Figures of Criminality in Indonesia, the Philippines, and Colonial Vietnam, ed V. Rafael. 95-127. Ithaca: Cornell University SEAsia Program.

Berman, Laine. 1999. “The Art of Street Politics.” In AWAS! : recent art from Indonesia ed. Hugh O'Neill, Timothy Lindsey et al. 75-77. Melbourne: Indonesian Arts Society.

Bourriaud, Nicolas. 2002. Relational aesthetics. France: Les presses du râeel.

Crosby, Alexandra. (2013) "Remixing environmentalism in Blora, Central Java 2005-10." International Journal of Cultural Studies 16.3: 257-269.

Crosby, Alexandra, Thajib, Ferdi, Juliastuti, Nuraini, and Lowenthal, Andrew. 2011. "A Chronicle of Video Activism and Online Distribution in Post-New Order Indonesia”. In Video Vortex Reader II: moving images beyond YouTube, Amsterdam: Institute of Network Cultures, ed Geert Lovink and Rachel Somers Miles. 178-195. Amsterdam: Institute of Network Cultures.

Crosby, Alexandra. 2007. "Festival Mata Air: A community takes a fresh look at water." Inside Indonesia 90, October-December. http://www.insideindonesia.org/weekly-articles/festival-mata-air

Echols, J.M., Shadily, H., Wolff, J.U. \& Collins, J.T. (1997), Kamus IndonesiaInggris: An Indonesian-English dictionary, 3rd edn, Jakarta: Gramedia.

Gee, James. 2005. "Social Social Spaces and Affinity Spaces: from the Age of Mythology to a Today's School.” In Beyond communities of practice: Language, power and social context ed. K. T. D Barton, 214-227Cambridge University Press

Hooker, Virginia Matheson. 1993. "New Order Language in Context.” In Culture and Society in New Order Indonesia ed Virginia Matheson Hooker 272-293. Kuala Lumpur, Singapore, New York: Oxford University Press.

Kursniasih, H. 2008. "Water Not For All: The Consequences Of Water: Privatisation In Jakarta, Indonesia" $17^{\text {th }}$ Annual Conference of the Asian Studies Association of Australia Melbourne, July 1-3.

Kwon, Miwon. 2002. One Place After Another: Site-specific Art and Locational 
Identity. Cambridge, Mass: MIT Press.

Lim, Merlyna. 2005. @rchipelago Online, The Internet and Political Activism in Indonesia, University of Twente. PhD.

Massey, Doreen. 1994. Space, Place and Gender Minnesota: University of Minnesota Press.

Rose, G. (1997) "Spatialities of 'community', power and change: the imagined geographies of community arts projects”, Cultural Studies, vol. 11, no. 1: 1-16.

Suara Merdeka. 2007. “Kompleks Pemandian Kalitaman Direlokasi” Suara Merdeka 26 November, http://www.suaramerdeka.com/harian/0711/26/kot23.htm Accessed 2 November 2011 